\title{
EVALUATION OF HYPOPLASTIC CLAY MODEL FOR DEEP EXCAVATION MODELLING
}

\section{MITEW-CZAJEWSKA ${ }^{1}$}

\begin{abstract}
This paper presents an evaluation of the Hypoplastic Clay constitutive model for finite element analysis of deep excavations and displacements induced by excavations in the influence zone. A detailed description and formulation of the Hypoplastic Clay soil model is included. A parametric case study of a deep excavation executed in Pliocene clays is presented. FE analysis was performed using several soil models (Mohr-Coulomb, Modified Mohr-Coulomb, Drucker-Prager, Modified Cam-Clay, Hypoplastic Clay) and the results were compared to in-situ displacements measurements taken during construction. Final conclusions concerning the suitability of the Hypoplastic Clay model for deep excavation modelling in terms of accurate determination of horizontal displacements of the excavation wall, the uplift of the bottom of excavation, and, most importantly, vertical displacements of the terrain in the vicinity of the excavation are presented.
\end{abstract}

Keywords: deep excavation, influence zone, FE modelling, soil models, hypoplastic model

\section{INTRODUCTION}

In Poland, in recent years, a big development in numerical modelling of geotechnical structures using Finite Element Method (FEM) has been observed. In the case of the design of retaining structures, the determination of internal forces and horizontal displacements of the excavation wall, the more time-effective dependent pressures method is usually applied [7]. When detailed analysis is necessary, e.g. evaluation of the influence of excavation on surrounding structures in order to assure its safety, the Finite Element Method is used [1], [6]. The choice of the most appropriate,

\footnotetext{
${ }^{1}$ PhD., Eng., Warsaw University of Technology, Faculty of Civil Engineering, Al. Armii Ludowej 16, 00-637 Warsaw, Poland, e-mail: m.mitew@il.pw.edu.pl
} 
constitutive soil model, together with correct definition of its parameters, is then the greatest challenge [4].

Over the years, Mohr-Coulomb is the most popular and widely used elastic-perfectly plastic constitutive model, both for the design and scientific purposes, due to the simplicity of its parameters. Howver, it should be noted that it has several limitations, and when applied to deep excavation analysis tends to result in excessive deformation of the wall and excessive settlements of the surrounding terrain, which is not observed in practice. Common observations for overconsolidated soils prove that terrain around the excavation rises during excavation (unloading) [1], while in numerical analysis settlements are obtained. Concepts of applying the Hardening Soil model in such cases are noted [13]. The author decided to evaluate the suitability of the hypoplastic model - Hypoplastic Clay, implemented in GEO5 FEM software [14], for modelling soil response during excavation basing on the experience described in [8] of the effective use of a hypoplastic model for tunnel excavation.

\section{DESCRIPTION OF THE HYPOPLASTIC CLAY MODEL}

The hypoplastic clay model is applicable for modelling of fine grain soft soils [14]. It belongs to the family of standard phenomenological models. As for description of soil response, it falls into the group of critical state models (Cam-Clay, Generalized Cam-Clay), and allows for reflecting a different stiffness in loading and unloading, and softening or hardening, in dependence with the soil compaction and the change of volume in shearing (dilation, compression). The current stiffness depends not only on the load direction, but also on the current state of soil given by its porosity. Unlike the Cam-Clay model, it strictly excludes tensile stresses in soil, see Fig. 1 (left).

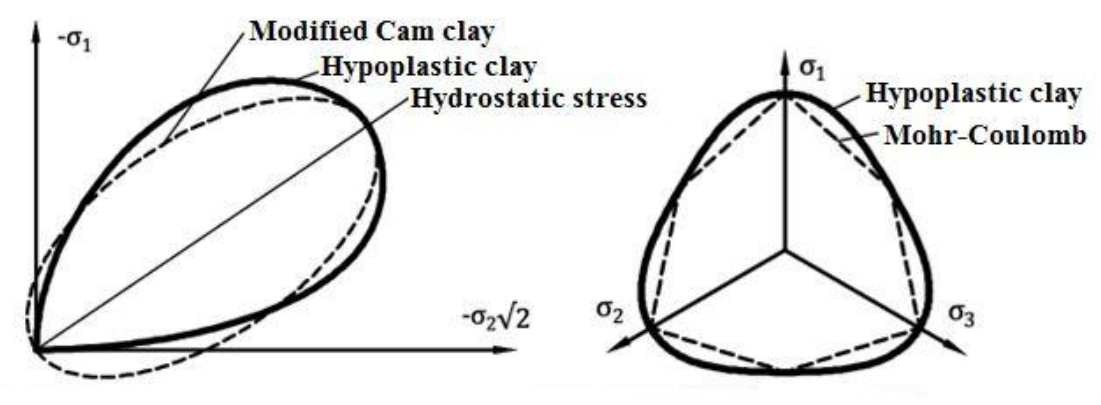

Fig. 1. State boundary of hypoplastic model: left - in the meridial plane, right - in the deviatoric plane 
In the case of the Hypoplastic Clay model, the standard yield surface is replaced by a so-called boundary state surface. Its projection into the deviatoric plane is shown at Fig. 1 (right). The nonassociated flow rule results into a non-symmetric stiffness matrix.

Mathematical formulation of the Hypoplastic Clay constitutive model [5].

Hypoplastic models are generally described by a single nonlinear tensorial equation yielding the stress rate $\dot{T}$ as a function of stretching rate $\mathrm{D}$ [8]. The general stress-strain relation is as follows:

$$
\begin{gathered}
\dot{\mathbf{T}}=f_{\mathrm{s}} L: \mathbf{D}+f_{s} f_{d} \mathrm{~N}\|\mathbf{D}\| \\
\mathrm{N}=\boldsymbol{L}:\left(-\mathrm{Y} \frac{\mathrm{m}}{\|\mathrm{m}\|}\right)
\end{gathered}
$$

The hypoelastic tensor $\boldsymbol{L}$ is

$$
\boldsymbol{L}=3\left(\mathrm{c}_{1} \boldsymbol{I}+c_{2} a^{2} \hat{\mathbf{T}} \otimes \hat{\mathbf{T}}\right)
$$

where 1 is the second order unity tensor, $\boldsymbol{I}=\frac{1}{2}\left(1_{i k} 1_{j l}+1_{i l} 1_{j k}\right)$ is a fourth-order unity tensor and

$$
\begin{array}{cc}
\operatorname{tr} \mathbf{T}=\mathbf{T}: 1, \quad \hat{\mathbf{T}}=\mathbf{T} / \operatorname{tr} \mathbf{T}, & \hat{\mathbf{T}}^{*}=\hat{\mathbf{T}}-1 / 3 \\
\mathrm{a}=\frac{\sqrt{3}\left(3-\sin \varphi_{\mathrm{c}}\right)}{2 \sqrt{2} \sin \varphi_{\mathrm{c}}} &
\end{array}
$$

The degree of nonlinearity $\mathrm{Y}$, with the limit value $\mathrm{Y}=1$ at Matsuoka-Nakai failure surface is calculated by

$$
\mathrm{Y}=\left(\frac{\sqrt{3} \mathrm{a}}{3+\mathrm{a}^{2}}-1\right) \frac{\left(I_{1} I_{2}+9 I_{3}\right)\left(1-\sin ^{2} \varphi_{\mathrm{c}}\right)}{8 I_{3} \sin ^{2} \varphi_{\mathrm{c}}}+\frac{\sqrt{3} \mathrm{a}}{3+\mathrm{a}^{2}}
$$

With stress invariants $I_{1}, I_{2}, I_{3}$,

$$
I_{1}=\operatorname{tr} \mathbf{T}, \quad I_{2}=\frac{1}{2}\left[\mathbf{T}: \mathbf{T}-\left(I_{1}\right)^{2}\right], \quad I_{3}=\operatorname{det} \mathbf{T}
$$

The tensorial quantity $\mathbf{m}$ defining the hypoplastic flow rule has the following formula: 


$$
\mathrm{m}=-\frac{\mathrm{a}}{\mathrm{F}}\left[\hat{\mathbf{T}}+\hat{\mathbf{T}}^{*}-\frac{\hat{\mathbf{T}}}{3}\left(\frac{6 \hat{\mathbf{T}}: \hat{\mathbf{T}}-1}{(F / a)^{2}+\hat{\mathbf{T}}: \hat{\mathbf{T}}}\right)\right]
$$

with factor $F$ given by

$$
\mathrm{F}=\sqrt{\frac{1}{8} \tan ^{2} \psi+\frac{2-\tan ^{2} \psi}{2+\sqrt{2} \tan \psi \cos 3 \theta}}-\frac{1}{2 \sqrt{2}} \tan \psi
$$

where

$$
\tan \psi=\sqrt{3}\left\|\hat{\mathbf{T}}^{*}\right\|, \quad \cos 3 \theta=-\sqrt{6} \frac{\operatorname{tr}\left(\hat{\mathbf{T}}^{*} \cdot \hat{\mathbf{T}}^{*} \cdot \hat{\mathbf{T}}^{*}\right)}{\left[\hat{\mathbf{T}}^{*}: \hat{\mathbf{T}}^{*}\right]^{3 / 2}}
$$

Barotropy and pyknotropy factors $f_{s}$ and $f_{d}$ are

$$
f_{\mathrm{s}}=\frac{\operatorname{tr} \mathbf{T}}{\lambda^{*}}\left(3+\mathrm{a}^{2}-2^{\alpha} \mathrm{a} \sqrt{3}\right)^{-1}, \quad f_{d}=\left[-\frac{2 \operatorname{tr} \mathbf{T}}{3 p_{r}} \exp \left(\frac{\ln (1+e)-N}{\lambda^{*}}\right)\right]^{\alpha}
$$

where $p_{r}$ is the reference stress $1 \mathrm{kPa}$ and the scalar quantity $\alpha$ is calculated by

$$
\alpha=\frac{1}{\ln 2} \ln \left[\frac{\lambda^{*}-\kappa^{*}}{\lambda^{*}+\kappa^{*}}\left(\frac{3+\mathrm{a}^{2}}{\mathrm{a} \sqrt{3}}\right)\right]
$$

Finally, factors $c_{1}$ and $c_{2}$ are calculated as follows:

$$
\mathrm{c}_{1}=\frac{2\left(3+\mathrm{a}^{2}-2^{\alpha} \mathrm{a} \sqrt{3}\right)}{9 \mathrm{r}}, \quad \mathrm{c}_{2}=1+\left(1-\mathrm{c}_{1}\right) \frac{3}{\mathrm{a}^{2}}
$$

Details regarding the development of the model and its formulation can be found in [5].

The Hypoplastic Clay model requires defining five constitutive parameters: angle of internal friction for constant volume $\varphi_{\mathrm{cv}}$, slope of swelling line $\kappa^{*}$, slope of the normal consolidation line $\lambda^{*}$, origin of the normal consolidation line $\mathrm{N}$, and ratio of unit and shear modulus $\mathrm{r}$.

Basic parameters $\kappa^{*}, \lambda^{*}$ and $\mathrm{N}$ may be determined from a bilinear diagram of isotropic consolidation in a log-log scale, Fig. 2 (left). In the GEO5 FEM software, however, they may be also calculated 
from parameters of the bilinear Cam-Clay model: slope of swelling line $\kappa$, slope of normal consolidation line $\lambda$ - in semi-logarithmic scale, Fig. 2 (right), void ratio $\mathrm{e}_{\max }$ for normal isotropic consolidation by pressure of $1 \mathrm{kPa}$. Detailed information on the interpretation of other model parameters may be found in [5] and [14].
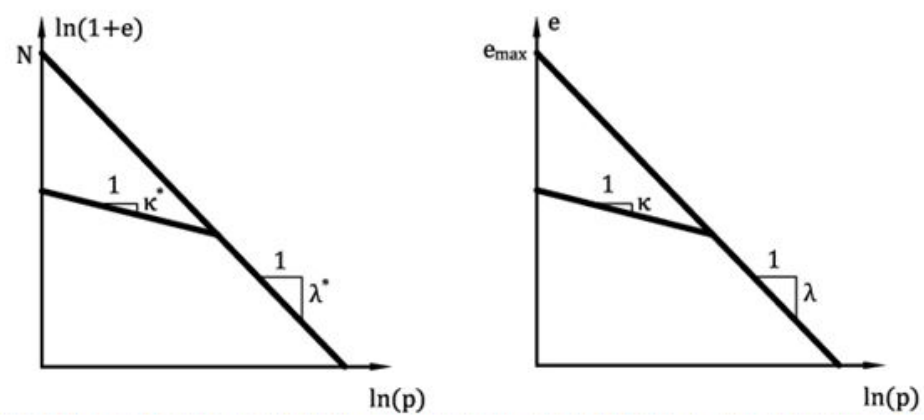

Fig. 2. Bilinear diagram of isotropic consolidation: left - Hypoplastic Clay, right - Cam-Clay

\section{HyPoplastic ClAy MODEL EVALUATION - CASE STUDY}

\subsection{GENERAL INFORMATION}

This case study concerns the analysis of a $14.6 \mathrm{~m}$ deep excavation executed in Pliocene clays [9], Fig. 3. The cut and cover method was used for the construction of the metro station; the stability of diaphragm walls during excavation was ensured by two levels of grouted anchors and one level of steel struts. The excavation was $20 \mathrm{~m}$ wide and approx. $150 \mathrm{~m}$ long. The following construction stages were distinguished and modelled in numerical FE analysis, Fig. 4:

Stage 1 - Greenfield

Stage 2 - Construction of the peripheral diaphragm walls

Stage 3 - Excavation - $4.55 \mathrm{~m}$ below ground surface (bgs)

Stage 4 - Installation and prestressing of the first row of anchors at $-3.73 \mathrm{~m}$ bgs, spacing $-2.4 \mathrm{~m}$

Stage 5 - Excavation $-8.85 \mathrm{~m}$ bgs, stressing of anchors $\left(\mathrm{F}=80 \%\right.$ of $\left.\mathrm{F}_{\mathrm{D}}, \mathrm{F}=400 \mathrm{kN}\right)$

Stage 6 - Installation and prestressing of the second row of anchors at $-7.85 \mathrm{~m}$ bgs, spacing $-1.3 \mathrm{~m}$

Stage 7 - Excavation - $11.85 \mathrm{~m}$ bgs, stressing of anchors $\left(\mathrm{F}=80 \%\right.$ of $\left.\mathrm{F}_{\mathrm{D}}, \mathrm{F}=480 \mathrm{kN}\right)$

Stage 8 - Installation of steel struts at $-10.85 \mathrm{~m}$ bgs $(\phi 508 / 14.2 \mathrm{~mm}$, spacing $2.0 \mathrm{~m})$

Stage 9 - Final excavation $-14.6 \mathrm{~m}$ bgs. 
Further construction stages - including construction of foundation plate and underground slabs were not modelled. The author decided to omit it as the results obtained in these stages are usually realistic; the loading is effectively modelled by geotechnical FE software.

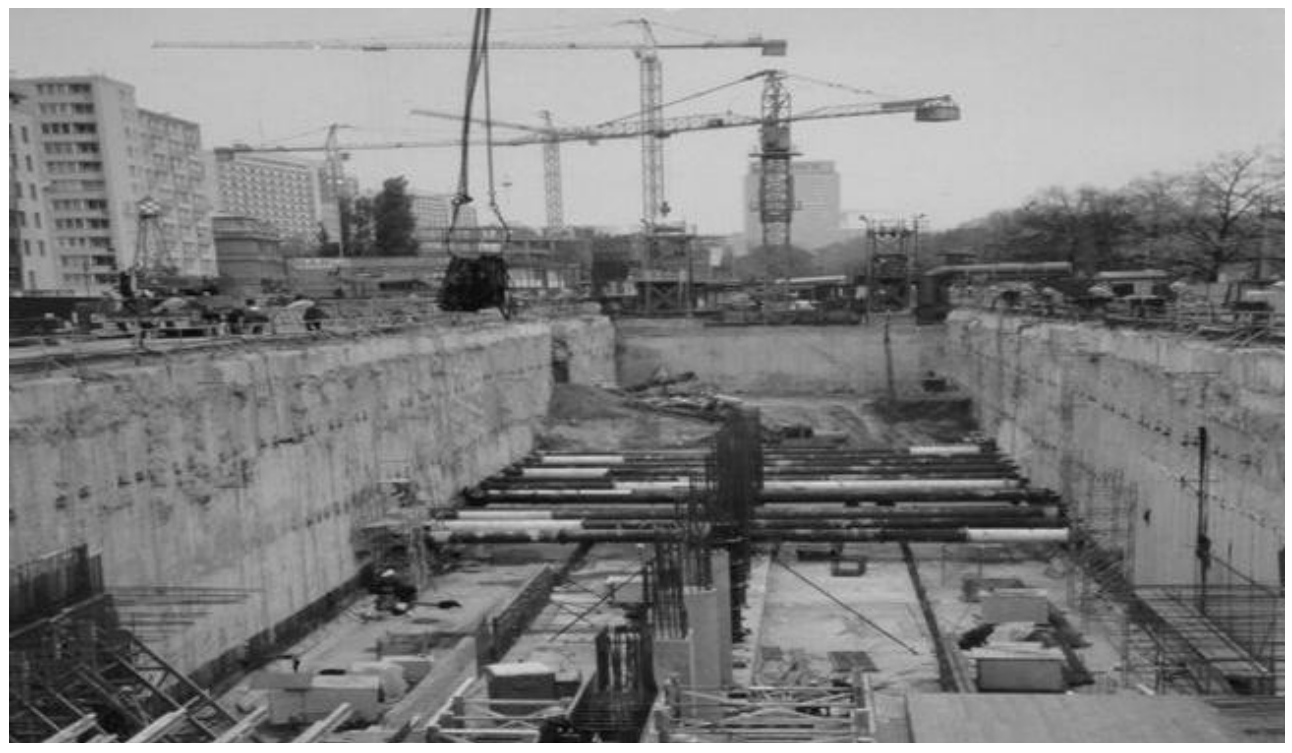

Fig. 3. Construction site

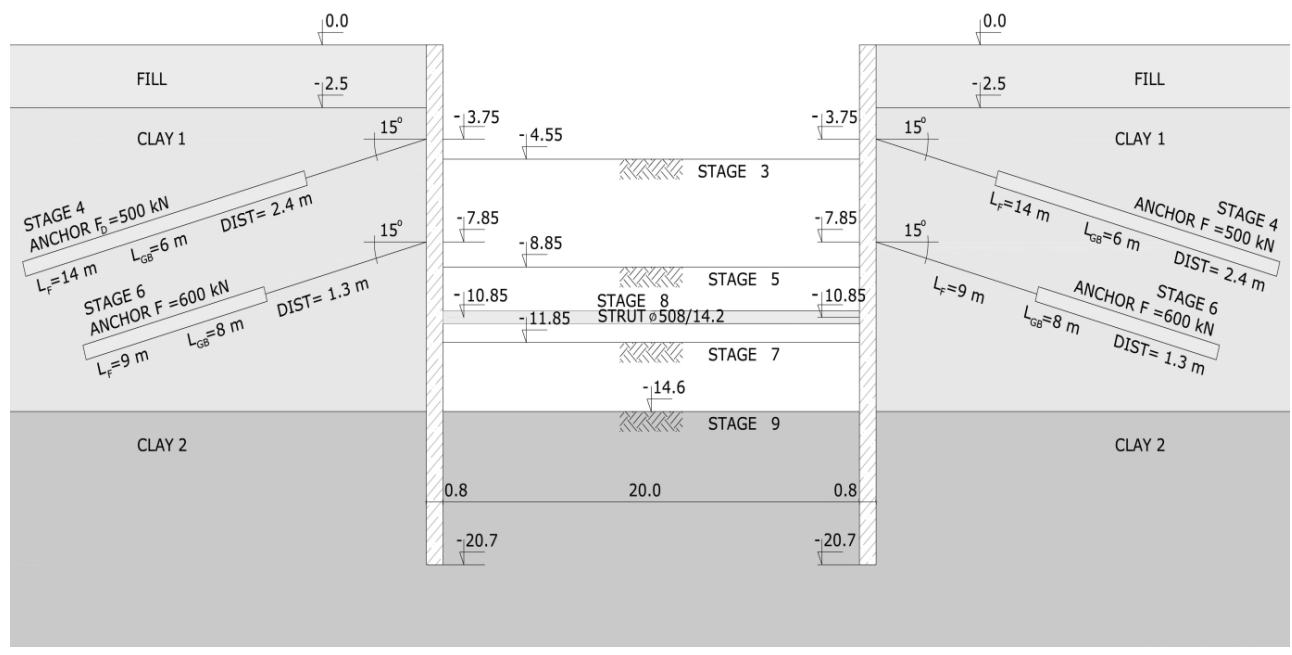

Fig. 4. Typical cross section including construction stages and geotechnical conditions 


\subsection{GEOTECHNICAL CONDITIONS}

In Warsaw, the subsoil is composed of Tertiary clayey deposits covered with a complex of Quaternary formations from the Pleistocene and Holocene periods. In the area of the analysed excavation, Tertiary, the Poznan formation clay layer is strongly elevated (due to glacitectonic and erosion processes). Detailed information about the Tertiary clay layer in Warsaw may be found in [2], [3], [10], [11], [12].

Soil conditions at the construction site and in the vicinity are as follows, Fig. 4:

- directly under the surface, $2.5 \mathrm{~m}$ thick anthropogenic soils (so called artificial fills, fills) occur,

- then, up to great depths, Poznań formation clay occurs. In the model, this layer is divided into two layers taking into account the change in its parameters with depth.

There is no general groundwater table in the analysed area. The groundwater table is discontinuous and carries low quantities of water. Water is located mostly in sand lenses and pockets within the clay body. As a result, water was not taken into consideration in the numerical model. Basic geotechnical soil parameters of all soil layers specified above (considered in the numerical analysis) are compiled in Tab. 1.

Table 1. Basic geotechnical parameters of soil layers

\begin{tabular}{|c|c|c|c|c|c|c|}
\hline & $\gamma$ & $\varphi^{\prime}$ & $\mathrm{c}^{\prime}$ & $\mathrm{E}$ & $\mathrm{Ko}$ & $\mathrm{v}$ \\
\cline { 2 - 7 } & $\mathrm{kN} / \mathrm{m}^{3}$ & $\mathrm{o}$ & $\mathrm{kPa}$ & $\mathrm{MPa}$ & - & - \\
\hline Fill & 18 & 25 & 0 & 25 & 0.577 & 0.30 \\
\hline Clay 1 & 20.7 & 18 & 10 & 80 & 0.917 & 0.35 \\
\hline Clay 2 & 20.7 & 18 & 15 & 100 & 0.783 & 0.35 \\
\hline
\end{tabular}

\subsection{NUMERICAL ANALYSIS}

Finite element plain strain analysis was carried out using GEO5 FEM software [14]. One typical geotechnical and structure geometry cross-section was modelled. The following basic assumptions were adopted: final excavation depth - $14.6 \mathrm{~m}$, diaphragm wall height $-20.7 \mathrm{~m}$, diaphragm wall thickness $-0.8 \mathrm{~m}$, two rows of anchors and one row of steel struts supporting the diaphragm wall. Construction stages and geometry details as specified in chapter 3.1, Fig. 4, geotechnical conditions and soil parameters as specified in chapter 3.2, Fig. 4, Tab. 1. 
Model dimensions are $40 \times 100 \mathrm{~m}$. Finite element mesh and model are shown at Fig. 5. FE model mesh, generated automatically, was built of 7048 nodes, 4189 elements (2641 15-nodes triangle surface elements, 387 beam elements, and 1161 contact elements). Anchors and struts are elements added in construction stages, after mesh generation.

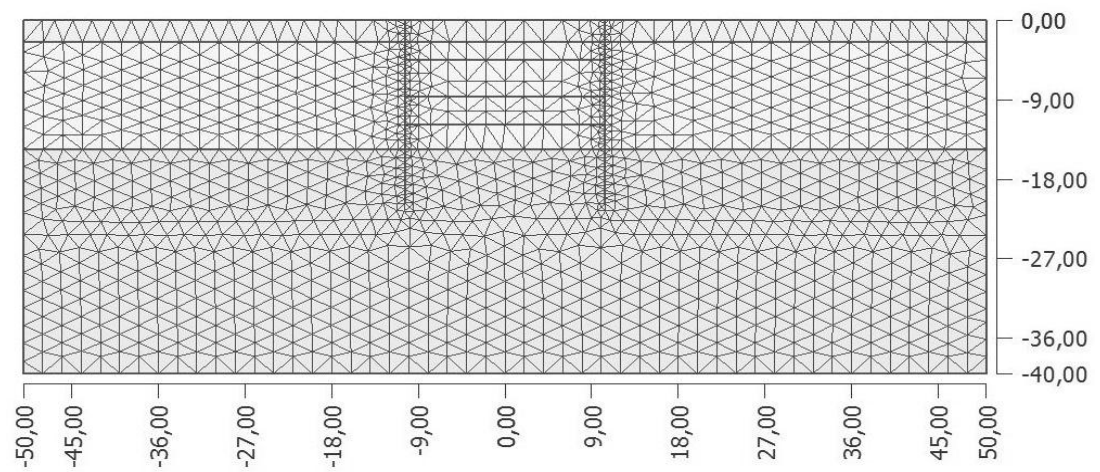

Fig. 5. Finite element mesh

For the basic model, an elastic perfectly plastic constitutive material model Mohr-Coulomb was chosen (calculation Series 1). Then the model was modified several times to: Modified MohrCoulomb (Series 2), Drucker-Prager (Series 3), Modified Cam-Clay (Series 4), and, finally, Hypoplastic Clay (Series 5). The parameters of Mohr-Coulomb, Modified Mohr-Coulomb, and Drucker-Prager models are given in Tab. 1. Parameters for clay layers defining the Modified CamClay and Hypoplastic Clay models are given in Tab. 2 and Tab. 3, respectively. All parameters except $\mathrm{e}_{\max }, \varphi_{\mathrm{cv}}$ and $\mathrm{r}$ for the $\mathrm{HC}$ model where established based on laboratory and field tests carried out at the Department of Geotechnics and Underground Structures of the Warsaw University of Technology [3], [10], [11], [12]. Parameters $e_{\max }, \varphi_{c v}$ and $r$ were taken as average for similar soil types [13]. Precise specification of all parameters of the Hypoplastic Clay model for Poznań formation clays will be a part of future study.

Table 2. Parameters of Modified Cam-Clay model

\begin{tabular}{|c|c|c|c|c|c|c|c|c|}
\hline & $\gamma$ & $v$ & Ko & OCR & $\mathrm{M}_{\mathrm{cs}}$ & $\kappa$ & $\lambda$ & $\mathrm{e}_{0}$ \\
\cline { 2 - 9 } & $\mathrm{kN} / \mathrm{m}^{3}$ & - & - & - & - & - & - & - \\
\hline Clay 1 & 20.7 & 0.35 & 0.917 & 2.5 & 0.710 & 0.019 & 0.071 & 0.57 \\
\hline Clay 2 & 20.7 & 0.35 & 0.783 & 1.5 & 0.710 & 0.019 & 0.071 & 0.57 \\
\hline
\end{tabular}


Table 3. Parameters of Hypoplastic Clay model

\begin{tabular}{|c|c|c|c|c|c|c|c|c|}
\hline & $\gamma$ & $\mathrm{Ko}$ & $\kappa$ & $\lambda$ & $\mathrm{e}_{0}$ & $\mathrm{e}_{\max }$ & $\varphi_{\mathrm{cv}}$ & $\mathrm{r}$ \\
\cline { 2 - 8 } & $\mathrm{kN} / \mathrm{m}^{3}$ & - & - & - & - & - & $\mathrm{o}$ & - \\
\hline Clay 1 & 20.7 & 0.917 & 0.019 & 0.071 & 0.57 & 2.5 & 27 & 0.3 \\
\hline Clay 2 & 20.7 & 0.783 & 0.019 & 0.071 & 0.57 & 2.5 & 27 & 0.3 \\
\hline
\end{tabular}

The results of all calculation series are further presented in form of graphs compared to geodesic insitu measurements in terms of: horizontal displacements of the top of the excavation wall in construction stages - Fig. 6, the uplift of the bottom of the excavation - Fig. 7, vertical displacements of terrain behind the excavation in four construction stages (representing successive excavation): stage 3 - Fig. 8, stage 5 - Fig. 9, stage 7 - Fig. 10, stage 9 - Fig. 11.

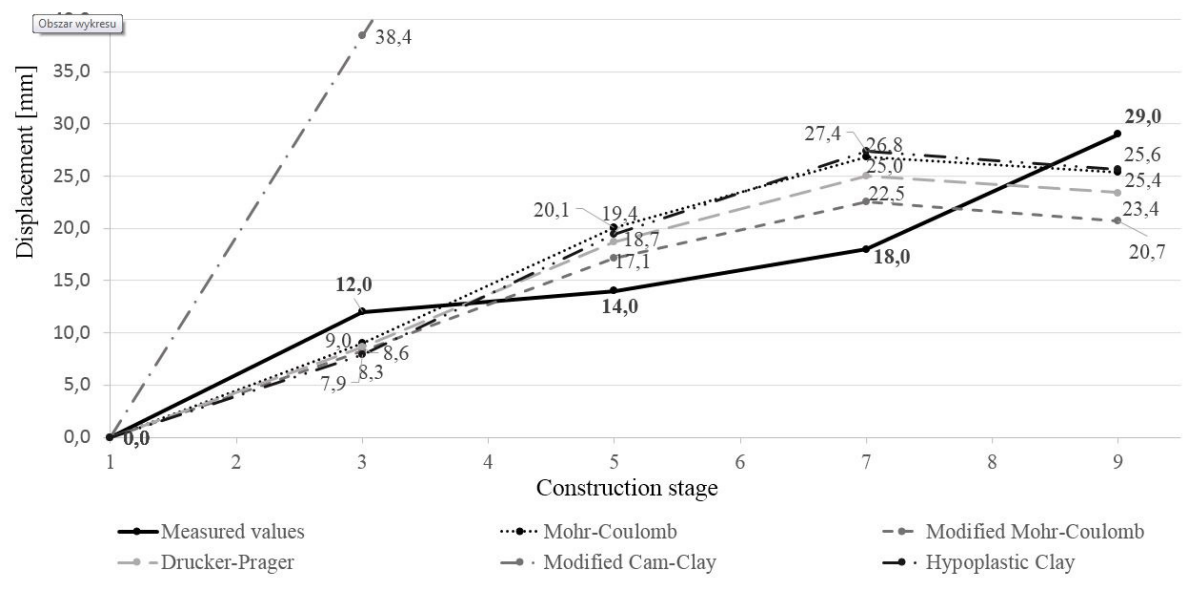

Fig. 6. Horizontal displacements of the excavation wall

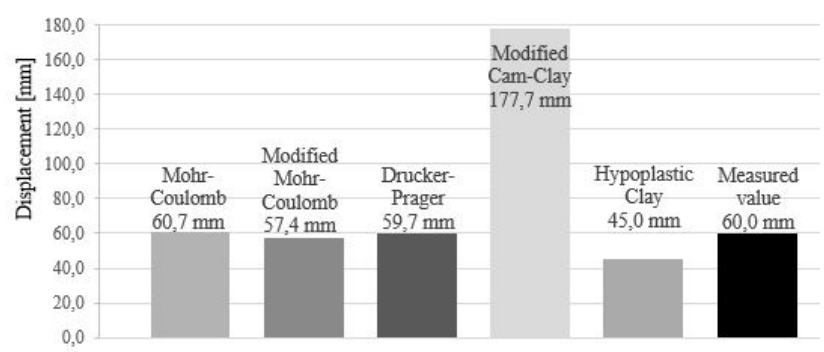

Fig. 7. The uplift of the bottom of the excavation 


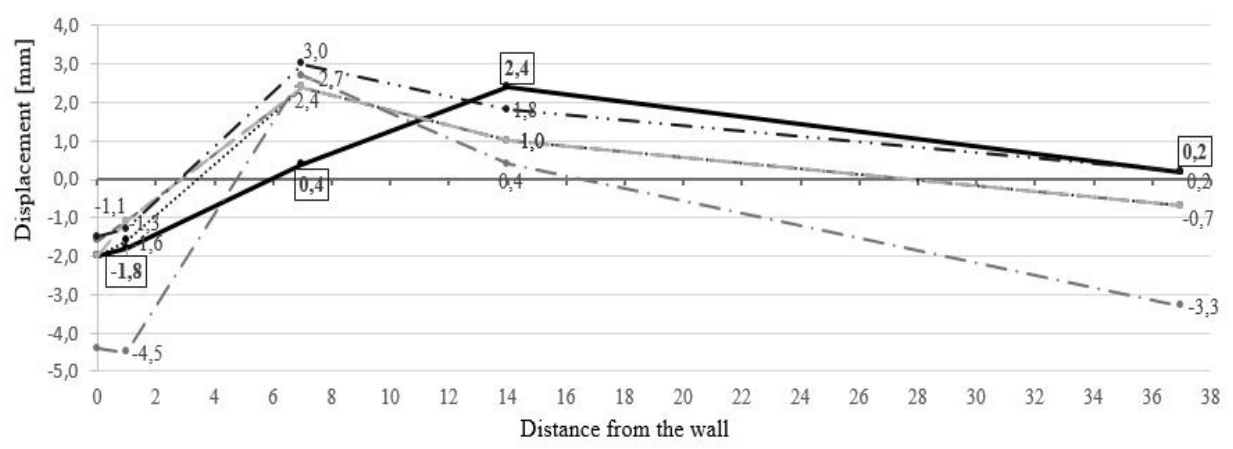

-Measured values $\cdots \cdot \cdots \cdot$ Mohr-Coulomb -- Modified Mohr-Coulomb $\rightarrow$-Drucker-Prager $\rightarrow \cdot$ Modified Cam-Clay $\rightarrow$. Hypoplastic Clay

Fig. 8. Vertical displacements of terrain - construction stage 3

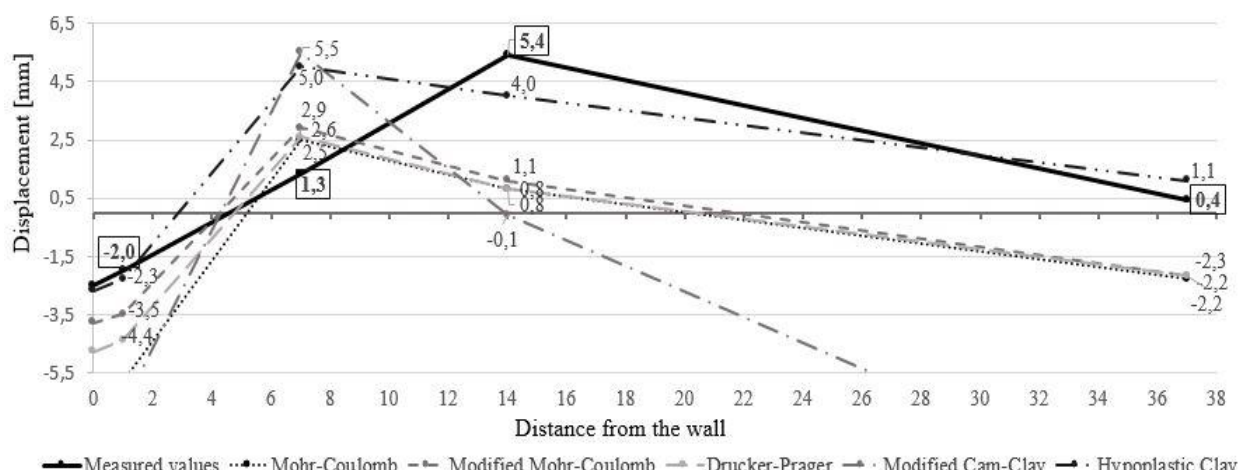

Fig. 9. Vertical displacements of terrain - construction stage 5

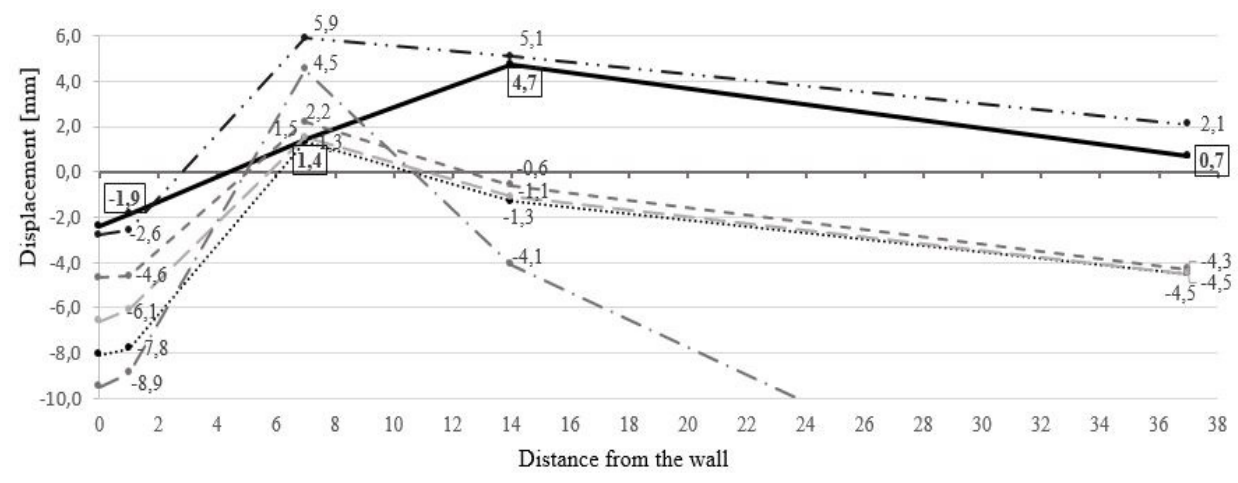

$\longrightarrow$ Measured values...$\cdot$ Mohr-Coulomb -- Modified Mohr-Coulomb $\rightarrow-$ Drucker-Prager $\rightarrow \cdot$ Modified Cam-Clay $\rightarrow$ - Hypoplastic Clay

Fig. 10. Vertical displacements of terrain - construction stage 7 


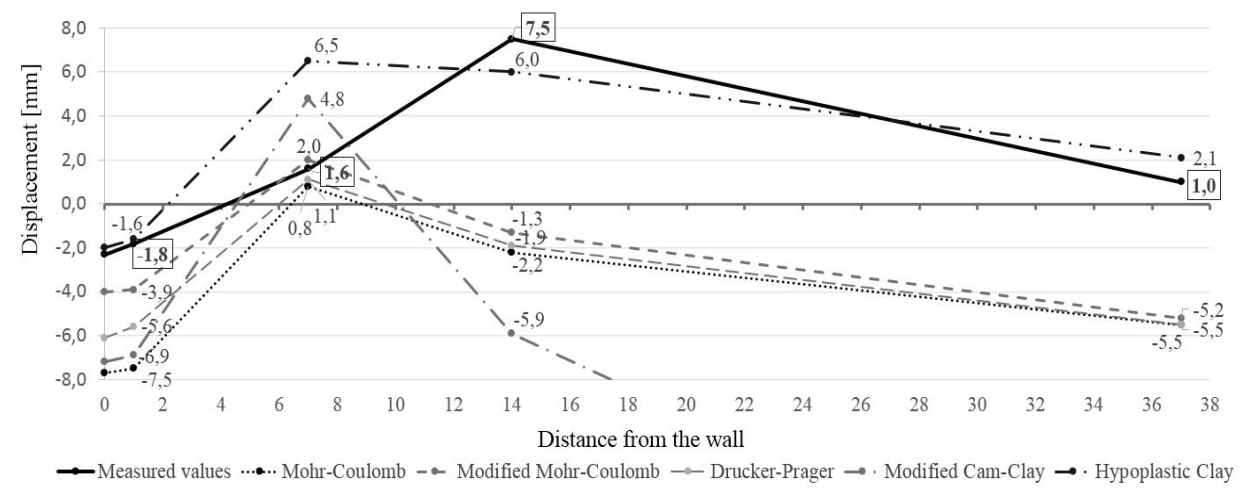

Fig. 11. Vertical displacements of terrain - construction stage 9

\section{SUMMARY AND CONCLUSIONS}

Based on the results of the analysis of the parametric case study it may be concluded that simple elastic perfectly plastic constitutive material models (Mohr-Coulomb, Modified Mohr-Coulomb, Drucker-Prager), with accurate calibration of their parameters may be used for the design of retaining walls embedded in Poznań formation clays. These models provide good estimates of both horizontal displacements of excavation walls (Fig. 6) and the uplift of the bottom of the excavation (Fig. 7).

It should be highlighted that appropriate, realistic results may only be obtained providing precise definition of soil parameters, especially the modulus of elasticity, resulting from special, dedicated soil testing campaigns for small strain ranges [2], [3], [11], [13]. On the contrary, these models do not perform very well in terms of the analysis of the influence of the excavation on surrounding terrain and structures. As mentioned before, in-situ displacement measurements usually show a raising of terrain behind the excavation walls, whereas in the same area the analysis (Series 1-3) performed using these models tends to result in settlements (Fig. 8-11).

Further observation based on the case study is that the critical state Modified Cam-Clay model (Series 4) is not suitable for modelling of pre-consolidated Poznań formation clays. This model significantly overestimates all analysed parameters (vertical and horizontal displacements of the structure and the soil body). 
Finally, as the main point of interest, it may be stated that the Hypoplastic Clay model (Series 5) proved to be fully suitable for modelling excavations made in Poznań formation clays specific for the area of Warsaw, both in terms of the design of excavation walls (Fig. 6) and the prediction of vertical displacements of terrain (Fig. 8-11). It should be pointed out that the use of this model resulted in a very good mapping of the slight raise of terrain observed in reality in all construction stages.

Though it may be concluded that the Hypoplastic Clay constitutive model is suitable for modelling deep excavations executed in Poznań formation Pliocene clays in Warsaw.

\section{REFERENCES}

1. T. Godlewski,"Observations of displacements induced by deep excavation on the example of A19 metro station in Warsaw”, Building materials 3/2008: 60-63. 2008. In polish.

2. T. Godlewski, G. Kacprzak, M. Witowski, „Practical evaluation of geotechnical parameters of soils for the design of diaphragm walls embedded in Warsaw's Pliocene clays", Civil and environmental engineering vol. 4, No.1: 13-19. In polish.

3. R. Kuszyk, M. Superczyńska, A. Lejzerowicz, "The methods of determination of elastic parameters of Pliocene clays for the $2^{\text {nd }}$ metro line in Warsaw", Transportation Overview 9: 59-63. 2012. In polish.

4. L. Kwaśniewski, M. Mitew-Czajewska, P. Kruszewski, "Verification of FEM Plain Strain Models of Underground Structures", The theoretical basis of construction. Vol. 3. Engineering structures, Publishing house of Warsaw University of Technology: 47-56. 2013.

5. D. Mašín, "A hypoplastic constitutive model for clays", International Journal for Numerical and Analytical Methods in Geomechanics 29, No. 4: 311-336, 2005.

6. M. Mitew-Czajewska, A. Siemińska-Lewandowska, "The effect of deep excavation on surrounding ground and nearby structures", Proceedings of the 6th International Symposium (IS-Shanghai 2008), Shanghai, China, Geotechnical Aspects of Underground Construction in Soft Ground / Ng C.W.W., Huang H.W., Liu G.B. (eds), CRC Press/Balkema: 201-206. 2009.

7. M. Mitew-Czajewska, "Numerical analysis of a $36 \mathrm{~m}$ deep diaphragm wall - parametric study", Geotechnical Aspects of Underground Construction in Soft Ground / Yoo Chungsik [et all.] (eds.), CRC Press: 257-262. 2014.

8. M. Ochmański, G. Modoni, J. Bzówka, Numerical analysis of tunnelling with jet-grouted canopy, Soils and Foundations 55 (2015): 929-942. 2015.

9. A. Siemińska-Lewandowska, "Analysis of anchored diaphragm walls displacements in the tunnels of the Warsaw Metro", Geotechnical Aspects of Underground Construction in Soft Ground. Proceedings of the 5th International Symposium TC28. Amsterdam, the Netherlands, 15-17 June 2005 Edited by E. A. Kwast, K. J. Bakker, W. Broere, and A. Bezuijen. Taylor \& Francis: 901-906. 2006.

10. M. Superczyńska, "Geology-engineering evaluation of Poznań formation clays as construction subsoil", PHD thesis, Warsaw University of Technology, 2015. In polish.

11. M. Superczyńska, "Values of the stiffness parameters of Poznań formation clays from Warsaw in small and medium strain ranges", Maritime Engineering and Geotechnics vol. 3/2015: 207-211, 2015. In polish.

12. M. Superczyńska, K. Józefiak, A. Zbiciak, "Numerical analysis of diaphragm wall model executed in Poznań clay formation applying selected FEM codes", Archives of Civil Engineering Vol. LXII, Issue 3: 207-224, 2016.

13. A. Truty, "Small strain stiffness of soils. Numerical modelling aspects. Technical transactions vol. 3-Ś/2008. Wydawnictwo Politechniki Krakowskiej: 107-126. 2008. In polish.

14. GEO5 User's manual. Fine Ltd. Prague 2016. 


\section{LIST OF FIGURES AND TABLES:}

Fig. 1. State boundary of hypoplastic model: left - in the meridial plane, right - in the deviatoric plane

Rys. 1. Powierzchnia stanu brzegowego modelu hypoplastycznego: z lewej-w płaszczyźnie południkowej, z prawej - w płaszczyźnie dewiatorowej

Fig. 2. Bilinear diagram of isotropic consolidation: left - Hypoplastic Clay, right - Cam Clay

Rys. 2. Wykres bilinearny konsolidacji izotropowej: z lewej- Hypoplastic clay, z prawej Cam Clay

Fig. 3. Construction site

Rys. 3. Fotografia z budowy

Fig. 4. Typical cross section including construction stages and geotechnical conditions

Rys. 4. Przekrój typowy uwzględniający fazy budowy i warunki geotechniczne

Fig. 5. Finite element mesh

Rys. 5. Siatka elementów skończonych

Fig. 6. Horizontal displacements of the excavation wall

Rys. 6. Poziome przemieszczenia ściany wykopu

Fig. 7. The uplift of the bottom of the excavation

Rys. 7. Odprężenie dna wykopu

Fig. 8. Vertical displacements of terrain - construction stage 3

Rys. 8. Przemieszczenia pionowe terenu - faza budowy - 3

Fig. 9. Vertical displacements of terrain - construction stage 5

Rys. 9. Przemieszczenia pionowe terenu - faza budowy - 5

Fig. 10. Vertical displacements of terrain - construction stage 7

Rys. 10. Przemieszczenia pionowe terenu - faza budowy - 7

Fig. 11. Vertical displacements of terrain - construction stage 9

Rys. 11. Przemieszczenia pionowe terenu - faza budowy - 9

Tab. 1. Basic geotechnical parameters of soil layers

Tab. 1. Podstawowe parametry geotechniczne warstw gruntowych

Tab. 2. Parameters of Modified Cam-Clay model

Tab. 2. Parametry modelu Modified Cam-Clay

Tab. 3. Parameters of Hypoplastic Clay model

Tab. 3. Parametry modelu Hypoplastic Clay 


\section{OCENA MODELU HYPOPLASTIC CLAY DO MODELOWANIA GLĘBOKICH WYKOPÓW}

Slowa kluczowe: głębokie wykopy, strefa wpływu, MES, modele materiałowe gruntów, model hypoplastyczny

\section{STRESZCZENIE}

W artykule przedstawiono ocenę modelu konstytutywnego stanu krytycznego Hypoplastic Clay (Ił hypoplastyczny) do analizy metodą elementów skończonych głębokich wykopów i oceny przemieszczeń w strefie ich wpływu. W pracy zawarto również szczegółowy opis i sformułowanie modelu Hypoplastic Clay. Zaprezentowano parametryczne studium przypadku dotyczące głębokiego wykopu wykonanego w Warszawie, w iłach plioceńskich formacji poznańskiej. Analizowany obiekt to wykop stacji metra o wymiarach 20x150m i głębokości $14.6 \mathrm{~m}$ wykonywany metodą odkrywkową z zastosowaniem dwóch rzędów kotew iniekcyjnych i jednego poziomu rozpór stalowych jako rozparcia. Analizę modelu przeprowadzono z zastosowaniem metody elementów skończonych, programem GEO5 MES, z uwzględnieniem kilku modeli materiałowych gruntu (Mohr-Coulomb, Modified Mohr-Coulomb, Drucker-Prager, Modified Cam-Clay, Hypoplastic Clay), a wyniki porównano z geodezyjnymi pomiarami przemieszczeń in-situ wykonanymi w trakcie budowy. Wnioski końcowe dotyczące przydatności zastosowanych modeli, a w szczególności modelu Hypoplastic Clay, do modelowania głębokich wykopów pod względem dokładnego określenia poziomych przemieszczeń ścian wykopu, odprężenia dna wykopu i co najważniejsze pionowych przemieszczeń terenu w sąsiedztwie wykopu są następujące:

- Proste modele sprężysto idealnie plastyczne (Mohr-Coulomb, Modified Mohr-Coulomb, Drucker-Prager) mogą mieć zastosowanie do projektowania obudów głębokich wykopów posadowionych w iłach plioceńskich formacji poznańskiej pod warunkiem prawidłowej kalibracji ich parametrów (zwłaszcza precyzyjnego określenia wartości modułu odkształcenia na podstawie właściwie dobranych badań in-situ, w zakresie małych odkształceń). Modele te właściwie odwzorowują wartości przemieszczeń poziomych ścian wykopu a także odprężenia dna wykopu. Nie powinny mieć jednak zastosowania do analizy wpływu wykopu na otoczenie ponieważ nie odwzorowują właściwie odprężenia związanego z odciążeniem wywołanym wykopem. W efekcie, zamiast obserwowanego zwykle unoszenia terenu sąsiadującego z wykopem w obliczeniach z zastosowaniem tych modeli uzyskuje się jego osiadanie.

- Model stanu krytycznego Modified Cam-Clay znacząco przeszacowuje wartości wszystkich analizowanych parametrów (przemieszczeń poziomych i pionowych, ścian i terenu), nie powinien mieć więc zastosowania do analizy wykopów wykonywanych w prekonsolidowanych iłach plioceńskich rejonu Warszawy.

- Wyniki analizy wykonanej z zastosowaniem ocenianego, szerzej omówionego, modelu Hypoplastic Clay wykazały bardzo dużą zgodność z wynikami pomiarów, zarówno w odniesieniu do wartości poziomych przemieszczeń ściany wykopu jak i w odniesieniu do pionowych przemieszczeń terenu. Należy podkreślić, że wyznaczone teoretyczne przemieszczenia pionowe terenu wokół wykopu bardzo precyzyjnie odwzorowują delikatne unoszenie terenu zaobserwowane w trakcie budowy we wszystkich fazach głębienia wykopu. Stwierdza się więc, że model ten może mieć zastosowanie do modelowania głębokich wykopów posadowionych w iłach plioceńskich. 